東大阪鋭敏粘土の堆積環境がその土質特性に与える影響十

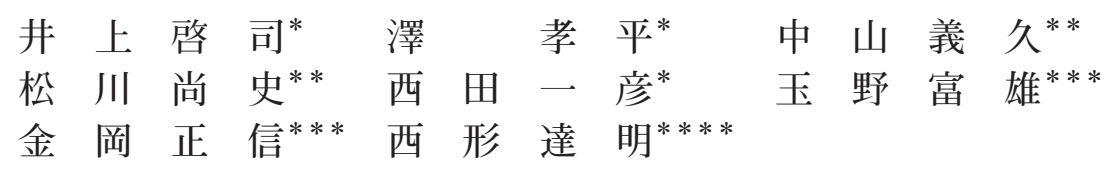

\title{
The Effects of Sedimentary Environment on Geo-Technical Properties of Higashi-Osaka Sensitive Clay
}

by

\author{
Keiji Inoue ${ }^{*}$, Kohei Sawa ${ }^{*}$, Yosihisa Nakayama ${ }^{* *}$, Hisashi Matsukawa ${ }^{* *}$, \\ Kazuhiko NishidA ${ }^{*}$, Tomio Tamano ${ }^{* * *}$, Masanobu KanaokA ${ }^{* * *}$ and Tatsuaki Nishigata ${ }^{* * * *}$
}

The undisturbed samples are obtained from the Higashi-Osaka sensitive clay area in the eastern part of Osaka. By the examination of physical, chemical and engineering properties of the clay, it is clear that the sedimentary environment, leaching and consolidation stress history have effects upon the clay properties, as follows.

The clay accumulates under two different types of environment, i.e. the upper is non-marine clay and the lower is marine one. The both clay are influenced considerably by leaching and become high sensitive clay. As the properties of bottom clay of the lower is close to those of non-marine clay because of the leaching and the over-consolidation state, the depth distributions of water content, void ratio and so on are bowed. The strength is mainly depended on the overburden pressure.

The consolidation properties of the sensitive clay are affected by the methods of loading, i.e. incremental loading and constant rate of strain loading. And the degree of soil structure appears in the overshoot of e-log p curve of constant rate of strain loading.

Key words : Consolidation properties, Leaching, Marine clay, Overshoot, Sensitive clay

\section{1 まえがき}

大阪市東部から東大阪市にかけて広く分布する通称 「東大阪鋭敏粘土」は，四方を山地と台地で囲まれた約 $5 \times$ $10 \mathrm{~km}$ の盆地部に堆積している. 新編大阪地盤図 ${ }^{1{ }^{1}}$ によ ると, 東大阪の沖積層は約 1 万年前より新しい年代に堆 積したものであり，その堆積環境は複雑である。1990 年 代に土質工学会（現地盤工学会）に設置された「堆積環 境が地盤特性に及ぼす影響に関する研究委員会」におい て, 大阪湾や有明湾など各地の粘土地盤の堆積環境と地 盤特性が研究されている。とくに，大阪湾の沖積粘土層 については, 多くの研究者が早い時期から堆積環境の違 いに着目し，研究してきた.2) 7) それらによると，東大阪 粘土は $\mathrm{OP}-5 \mathrm{~m} \sim-7 \mathrm{~m}$ 付近で堆積環境が変化して打り, 上部は非海水成の堆積粘土であり，下部は海水成の堆積 粘土である (Fig. 1 (b))。 そして, 海水成層と非海水成層 の違いに基づく塩分含有量・コンシステンシー特性・カ 学特性などが明らかにされている.

本研究では, 東大阪鋭敏粘土の不摚乱試料の連続サン プリングを行い，珪藻化石分析と花粉分析の後，採取深 度約 $10 \mathrm{~cm}$ 間隔ごとに物理試験，塩分含有量試験，強熱 減量試験, $\mathrm{pH}$ 試験, 一軸圧縮試験, 段階載荷圧密試験,

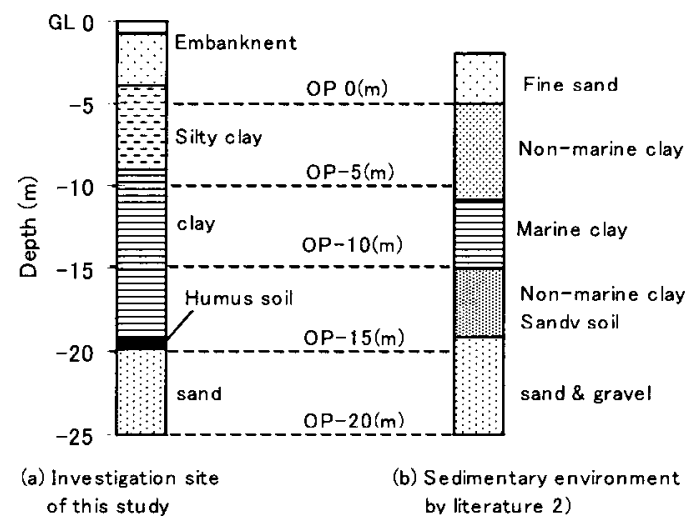

Fig. 1 Soil profile of the boring site.

定ひずみ速度圧密試験を実施した。これらの分析・試験 結果により，堆積環境が土質特性とくに圧密特性に与え る影響を明らかにする。

\section{2 採取地盤の堆積環境}

本研究の対象とした粘土の不擋乱連続試料は, 大阪府 大東市深町のボーリング現場から固定式シンウォールサ ンプラーを用いて採取した。笛の柱状図 (Fig. 1 (a)) によ ると，粘土が GL-3.85m 〜 -19.30m に分布し， GL-9.0m

\footnotetext{
$\dagger$ 原稿受理 平成 19 年 5 月 10 日 Received May 10, 2007 @ 2008 The Society of Materials Science, Japan

* 正 会 員 協同組合関西地盤環境研究センター †566-0042 捸津市東別府, Kansai Geo-Environment Res. Center, Higashibehu, Settsu, 566-0042

**＼cjkstart協同組合関西地盤環境研究センター ₹566-0042 攝津市東別府, Kansai Geo-Environment Res. Center, Higashibehu, Settsu, 566-0042

$* * *$ 正 会 員 大阪産業大学工学部都市創造工学科 ₹574-8530 大東市中垣内, Dept. of Civil Eng., Osaka Sangyo Univ., Nakagaiti, Daitou, 574-8530

$* * * *$ 正 会 員 関西大学工学部環境都市工学科＝564-8680 吹田市山手町, Dept. of Civil \& Environment Eng., Kansai Univ., Yamate, Suita, 564-8680
} 
付近まではシルト質粘土（GL-5m 付近に腐植物が混入） で，さらに GL-19.30m まで軟弱な粘土が連続して堆積 している。その下の GL-19.30m 〜-19.90m には腐植土 層が存在する. GL-3.85m 〜 $19.30 \mathrm{~m}$ の粘土層の $\mathrm{N}$ 值 （約 $30 \mathrm{~m}$ 離れた地点の測定值）は，全層厚を通じ $0 \sim 2$ と非常に軟弱である。

この調査地点の堆積環境を以下の 3 点に基づき推定 した.

(1) 大阪平野の古地理発達史 ${ }^{1)}$ : 河内盆地は約 4000 年 前までは縄文海進により生成されたと言われる河内湾で あり，その後約 3000 年前からは淡水域であったとされ ている。その間に汽水域の時代が存在していたと推定で きる。

(2) 既往調査結果 ${ }^{2)}$ : 今回の調查地点から約 $3 \mathrm{~km}$ 離れ た地点の柱状図は Fig. 1 (b)であり, この沖積粘土の微化 石分析によると，上部は非海水成（汽水成一淡水成）粘土， 下部は海水成粘土である，それらの境界は $\mathrm{OP}-5 \mathrm{~m} \sim-7 \mathrm{~m}$ （今回の調査地点の $\mathrm{GL}-10 \mathrm{~m} \sim-12 \mathrm{~m}$ に相当する）と推 定されている.

(3) 珪藻化石分析打よび花粉分析：採取粘土の上部 $(\mathrm{GL}-5.35 \mathrm{~m} \sim-7.95 \mathrm{~m})$ と下部 $(\mathrm{GL}-17.60 \mathrm{~m} \sim-18.60 \mathrm{~m})$ に おいて，珪藻化石分析および花粉分析を実施した。珪藻 化石分析結果 (Table 1) によると, GL-6.05〜-6.15m の 試料 (T-4) と GL-7.85 〜 - 7.95m の試料 (T-6) には珪藻款 が全く見られず，他の深さでは海水性珪藻と淡水性珪藻 が同程度見られる。一方，花粉分析結果 (Fig. 2) によると， 粘土層の上部 $(\mathrm{T}-3 \cdot \mathrm{T}-5)$ と下部 $(\mathrm{T}-17 \cdot \mathrm{T}-18)$ の 2 グ ループに分けられる。そして，花粉種から判断して，下部 は約 8000 年前の温帯性落葉樹の時代に，上部は約 4000

Table 1 Results of the analysis of fossil diatoms.

\begin{tabular}{|c|c|r|r|c|}
\hline \multirow{2}{*}{ io. } & \multirow{2}{*}{$\begin{array}{c}\text { Depth } \\
\text { GL- (m) }\end{array}$} & \multicolumn{2}{|c|}{$\begin{array}{c}\text { Frequency } \\
\text { of fossil diatoms }\end{array}$} & \multirow{2}{*}{$\begin{array}{c}\text { Sedimentary } \\
\text { envi ronment }\end{array}$} \\
\cline { 3 - 5 } & & Mar ine & Limnet ic & \\
\hline $\mathrm{T}-3$ & $5.35 \sim 5.45$ & ++ & & Marine \\
\hline $\mathrm{T}-4$ & $6.05 \sim 6.15$ & - & - & \\
\hline $\mathrm{T}-5$ & $6.95 \sim 7.05$ & + & + & Brackish \\
\hline $\mathrm{T}-6$ & $7.85 \sim 7.95$ & - & - & \\
\hline $\mathrm{T}-17$ & $17.60 \sim 17.70$ & ++ & + & Brackish \\
\hline $\mathrm{T}-18$ & $18.50 \sim 18.60$ & + & + & Brackish \\
\hline
\end{tabular}

Liquid limit $w_{1}(\%)$ Water content $w(\%)$ (under $2 \mu \mathrm{m}$ ) $P_{2 \mu \mathrm{m}}(\%) \quad$ Void ratio $e$ $0 \quad 20 \quad 40 \quad 60 \quad 0$
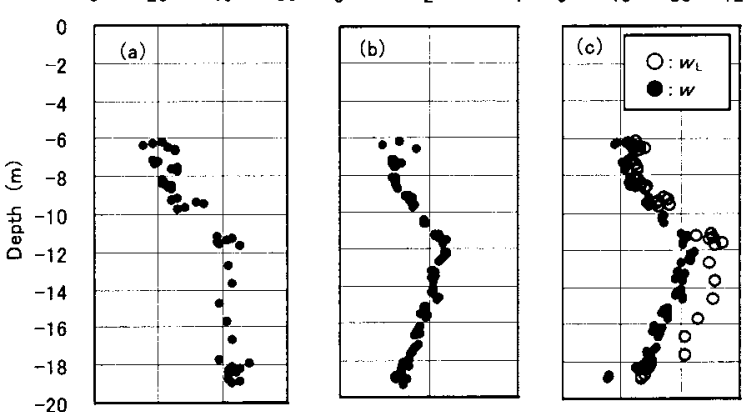

Ignition loss (\%)

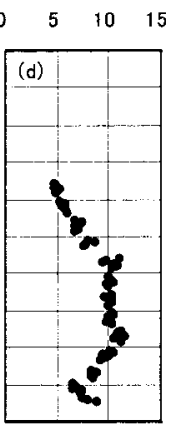

\begin{tabular}{|ll|}
\hline Oarboreal pollen & $\mathbb{1}$ nonarboreal pollen \\
Qfern spores & $\square$ unknown \\
\hline
\end{tabular}

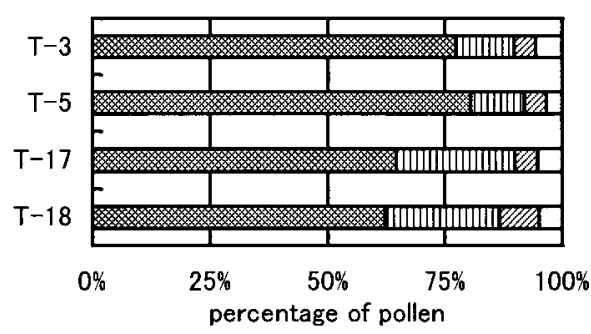

Fig. 2 Result of Pollen Analysis.

年前以降の暖温帯性常緑広葉樹林の時代に堆積したと推 定される。

すなわち，今回の分析のみでは境界深度が明確ではな いが，(1)(3)より下部は縄文海進時期に，上部は淡水時期 に堆積したものと言える。さらに，(2)の結果を参考にし て，今回の調査地点の粘土は $\mathrm{GL}-10 \mathrm{~m} \sim-12 \mathrm{~m}$ を境にし

て，上部は汽水成あるいは淡水成，下部は海水成と推定 できる。

\section{3 物理・化学的性質から見た東大阪粘土の特性}

採取粘土の物理的・化学的特性を明らかにするため, シンウォールチューブ内の試料を出来るだけ細かく（ほ ほ $10 \mathrm{~cm}$ 間隔に）区分した。Fig. 3 に深度方向に測定し た粘土の物理的性質と化学的性質を示す. Fig. 3 (a)の 粒度特性 $\left(2 \mu \mathrm{m}\right.$ 通過百分率 $\left.: P_{2 \mu \mathrm{m}}\right)$ によると, $P_{2 \mu \mathrm{m}}$ は GL-9m より浅い位置では約 $20 \%, G L-12 m$ より深い位置 では約 45\% とほぼ一定值であり，GL-9m〜-12m では， $20 \%$ ～45\% に漸増している。粒度特性は堆積時の地形的 環境に基づき，一般には水深の深い場合に細粒となるの で，GL-12m より深い堆積層は水深の大きな海進時期に 形成されたものと判断でき，2で推定した海水成の境を GL-12m と考える。さらに, GL-9m 以浅は水深の浅い 淡水時期に堆積したものと考えられ，GL-9m 〜 - 12m を 汽水時期の堆積層と見ることができる.

従って，本論文では調查地点の粘土を次の 3 つに区分 してそれぞれの特性を検討する。すなわち，上部（GL$9 \mathrm{~m}$ 以浅) の淡水成粘土，下部 (GL-12m 以深) の海水 成粘土，およびそれらの中間部 $(\mathrm{GL}-9 \mathrm{~m} \sim-12 \mathrm{~m})$ の汽 水成粘土である。

次に, Fig. $3(\mathrm{e})$ の塩分含有量 $(\mathrm{Cl}$ 量) に着目すると,

Fig. 3 Physical and chemical properties of clay. 
$\mathrm{GL}-9 \mathrm{~m} \sim-12 \mathrm{~m}$ の汽水域では浅いほど $\mathrm{Cl}$ 量が小さく， 海水域から淡水域への変化に対応している。同じように 考えると, GL-16m 以深の粘土は深いほど $\mathrm{Cl}$ 量が小さく， 淡水域に近づくようにみえる。さらに, Fig. 1 (a)による と，GL-19.3m 以深には腐植土があり，縄文海進以前の 海退期に陸域で繁茂した植物を起源としている可能性も 否定できない.

海水成粘土は，リーチングにより $\mathrm{Cl}$ 量が減少し，それ に伴い液性限界や塑性指数が低下する. ${ }^{8}$ 海水の $\mathrm{Cl}$ 量は $32 \sim 35 \mathrm{~g} / 1$ であり, 有明粘土では, リーチングを受けた 粘土の $\mathrm{Cl}$ 量が $2 \sim 6 \mathrm{~g} / 1$, リーチングを受けていないも のは最大 $20 \mathrm{~g} / 1$ (平均 $11.1 \mathrm{~g} / 1$ ) である. ${ }^{9)}$ 大阪平野の沖積 粘土に打ける過去の調查結果 ${ }^{10)}$ の内, OP-10m 〜 $-20 \mathrm{~m}$ のデータによると, 現在の海に近い地点の $\mathrm{Cl}$ 量は高く (30 10g/l) , リーチングの影響が少ないが, 内陸に向か うほど $\mathrm{Cl}$ 量は低くなり $(4 \sim 6 \mathrm{~g} / \mathrm{l})$, 東大阪の鋭敏粘土の $\mathrm{Cl}$ 量は $0.2 \sim 2 \mathrm{~g} / 1$ まで低下し, リーチングの影響が見ら れる。これらと比較すると，今回の海水成粘土の $\mathrm{Cl}$ 量は $1.5 \sim 4.5 \mathrm{~g} / 1$ であり (Fig. 3 (e)), リーチングを受けてい ると判断できる.

一方，リーチングを受けた粘土は，練り返し強度の減 少とともに鋭敏比を増大させることになる.9)鋭敏比と $\mathrm{Cl}$ 量の関係を深さごとにプロットすると, Fig. 4 となる. ○は淡水成粘土であり，もともと塩分は含まれていない。 $\square$ $\square \mathrm{Cl}$ 量が小さく，海水成粘土が極度にリーチングを受 けていると判断できるが，鋭敏比が小さいことから判断 して，○と同様に淡水成と考える方が妥当である。山は 海水成粘土がリーチングを受けた結果，鋭敏比が大きく 現れている。と＋は○ $\times$ との中間であり，淡水成か ら海水成へ遷移する領域，すなわち汽水成と推定できる.

以上の検討と推定をまとめたものが, Fig. 5 である.

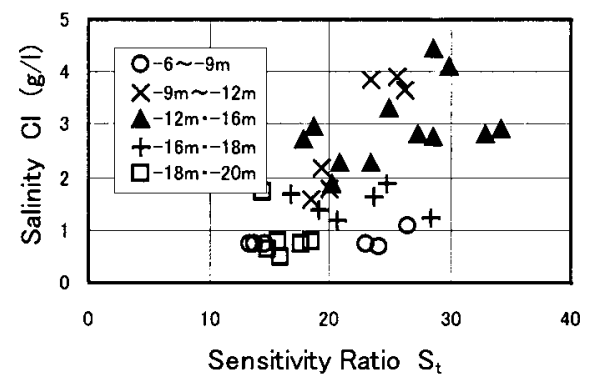

Fig. 4 Sensitivity ratio and Salinity.

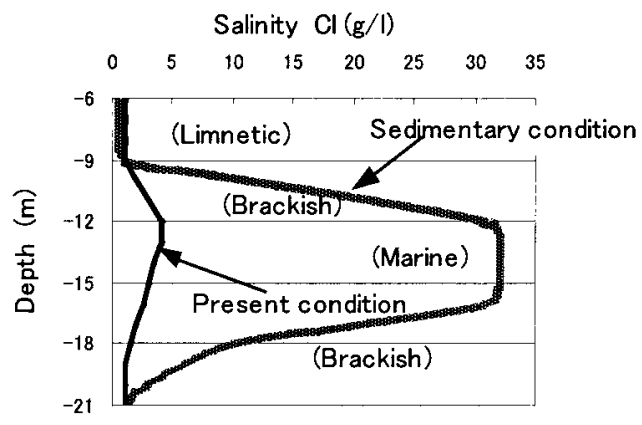

Fig. 5 Estimation of sedimentary environment.
海水成粘土 $(\mathrm{GL}-12 \mathrm{~m} \sim-16 \mathrm{~m})$ の堆積時の $\mathrm{Cl}$ 量は, 海 水と同じ $32 \mathrm{~g} / 1$ と仮定し, 現在の $\mathrm{Cl}$ 量 $(1 \sim 4.5 \mathrm{~g} / \mathrm{l})$ と の差がリーチングの影響と考える。なお， GL-6m 〜 - $9 \mathrm{~m}$ の淡水成粘土中の $\mathrm{Cl}$ 量は，リーチング過程で集積した ものである. GL-9m 〜 - 12m の汽水成粘土は海退時に海 水が淡水化する途上の堆積環境である。また，海水成粘 土下層部（ここでは GL-18m 以深と仮定）は，淡水成に 近い環境下であり，GL-16m〜-18m は海進の影響によ り海水が浸水して生じる領域で，後にリーチングの影響 も現れるために， $\mathrm{Cl}$ 量の変化は複雑であると考えられる.

Fig. 1 (b)〜 (d) に示されている間隙比, 含水比, 液性 限界打よび強熱減量は, Fig. 5 の堆積環境と同様に, GL-12m 〜-16m において極大值を有する弓形分布であ り，東大阪鋭敏粘土の特徵の一つとされている。この地 域では, Fig. 5 に示した堆積の 1 サイクル（下層から淡 水域一汽水域一海水域一汽水域一淡水域）が完成してい て，これに粒度組成，リーチングによる高間隙化・高含 水比化，さらに後述する圧密現象による低間隙化・低含 水比化が関係して，弓形の特徴的な深度分布が見られる と考えられる。

\section{4 力学的性質から見た東大阪粘土の特徵 $4 \cdot 1$ 一軸圧縮強度}

Fig. 6 は，GL-11m と GL-17m の粘土の一軸圧縮試 験における応力ーひずみ曲線である，不擋乱試料の応 力ーひずみ曲線は，急激な立ち上がりを示し，破壊ひず みが 2 〜 $3 \%$ であり, 試料の乱れは少ないものと判断され る。一方，練り返した試料の応力ーひずみ曲線は，圧縮 強度が非常に小さい，鋭敏比 $S_{\mathrm{t}}$ は，GL-11m 試料が $S_{\mathrm{t}} \fallingdotseq$ $25, \mathrm{GL}-17 \mathrm{~m}$ 試料が $S_{\mathrm{t}} \fallingdotseq 20$ であり，東大阪の鋭敏粘土 の特性を示している. 前述の Fig. $3(\mathrm{~g})$ においても，この 調査地点の粘土は, 全体的に $S_{\mathrm{t}}=15 \sim 35$ である. とく に, Fig. 5 において海水成と推定した GL-11m〜 - $16 \mathrm{~m}$ 付近では $S_{\mathrm{t}}=25 \sim 35$ であり，超鋭敏粘土といえる.

Fig. 7 は, 一軸圧縮強度 $q_{\mathrm{u}}$ および変形係数 $E_{50}$ の深度 分布を表している。一軸圧縮強度 $q_{\mathrm{u}}$ と変形係数 $E_{50}$ は深 度方向にほほ直線的に増加しており，堆積環境にあまり 関係せず，罒中に示した有効土被り圧 $p_{0}$ とほぼ比例関係 にあるといえる。

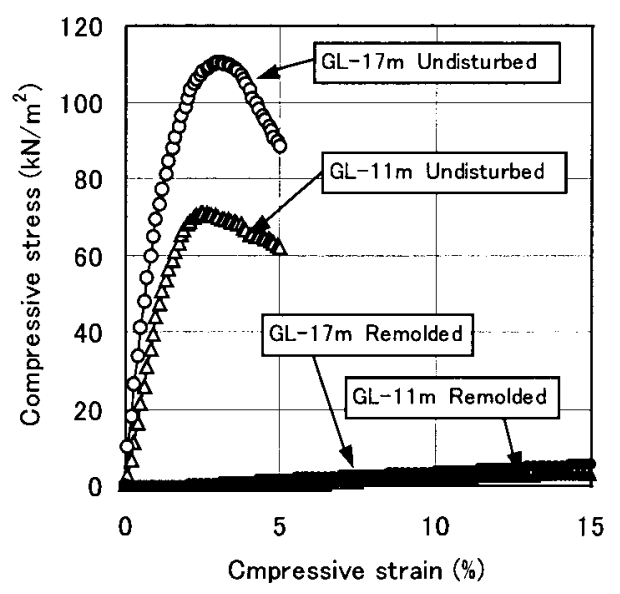

Fig. 6 Stress-strain curves. 


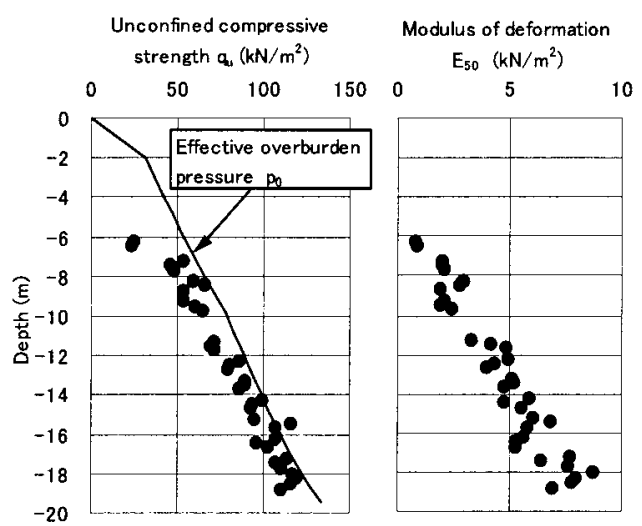

Fig. 7 Results of unconfined compression test.

\section{$4 \cdot 2$ 圧密特性}

Fig. 8 は, 鋭敏比の異なる粘土 (GL-11m と GL-17m)に ついて,JISA1217 に基づく段階載荷圧密試験(Incremental loading test：図中では「IL」と略記）とひずみ速度 $0.01 \% /$ $\min$ の定ひずみ速度圧密試験（Constant rate of strain loading test：図中では「CR」と略記）で求めた $e-\log p$ 曲線を表している。压密降伏応力 $p_{\mathrm{c}}$ は，定ひずみ速度圧 密試験の方が段階載荷圧密試験のものより大きく求めら れている。 その差は GL-11m の方が GL-17m のものより 大きい。また，段階載荷圧密試験の $e-\log p$ 曲線は, $p$ c 以上の正規圧密状態の圧力に対して，なめらかに直線に

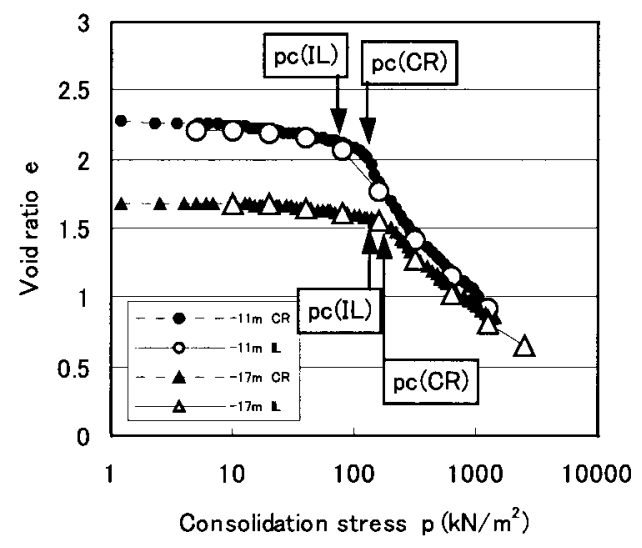

Fig. $8 \quad e-\log p$ curves.

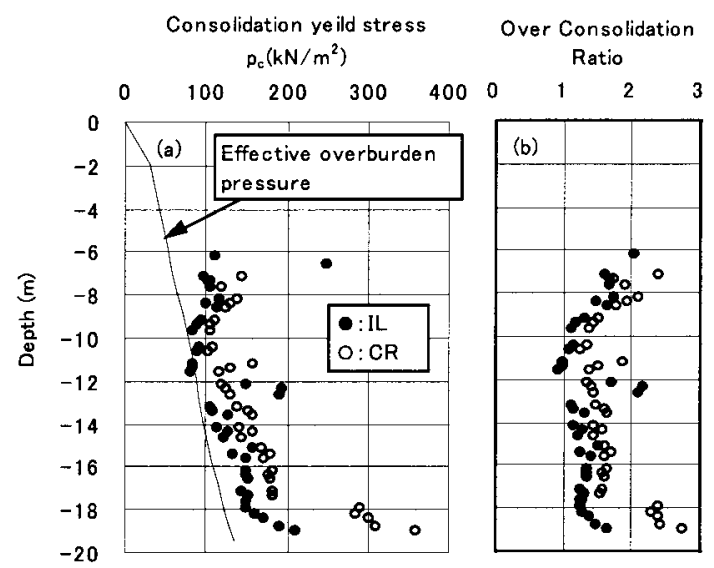

Compression Index $C_{0}$

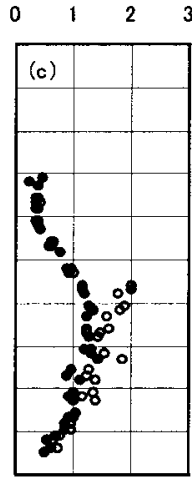

移行している。一方，定ひずみ速度圧密試験では， $p_{\mathrm{c}}$ 以 上の圧力に対する $e-\log p$ 曲線の曲率が極端に大きくな り, $p_{\mathrm{c}}$ 直後の曲線が右に飛び出し（これをオーバーシュー 卜ということがある $\left.{ }^{6)}\right)$, 圧縮指数 $C_{\mathrm{c}}$ は段階載荷圧密試 験のものよりも大きな值を示すことになる。この原因は， 両圧密試験のひずみ速度の違いが関係して扔り，今回の 定ひずみ圧密試験のひずみ速度は段階載荷圧密試験の平 均ひずみ速度の約 3.5 倍である。このようなオーバーシュー 卜現象は，大阪湾海域の海水成粘土に打ける擬似過圧密 性の状況に類似な現象 ${ }^{6}$ であり，東大阪の鋭敏粘土では とくに顕著に現れ，定ひずみ速度圧密試験の $p_{\mathrm{c}}$ と段階載 荷圧密試験の $p_{\mathrm{c}}$ との差は，一般の沖積粘土に比べて大き くなる.

Fig. 9 (a) は，2つの圧密試験方法で得られた $p_{\mathrm{c}}$ を深 度方向に表したものである。 $p_{\mathrm{c}}$ の分布形状は 2 つの圧密 試験方法でよく似ているが，定ひずみ速度圧密試験の $p_{\mathrm{c}}$ が少し大き目の值となっている。 また, 図中の実線は有効 土被り圧 $p_{0}$ を示しており，GL-11m 付近の段階載荷圧密 試験以外は $p_{\mathrm{c}}$ が $p_{0}$ より大きく, 過圧密状態である. Fig. 9 (b)には過圧密比の深度分布を示した。とくに, GL-9m より浅い粘土と GL-18m より深い粘土は過圧密比が大き く, 压密がかなり進行している。堆積環境からみると, 過 圧密比の大きい粘土は非海水成であり，Fig. 3 (b)，(c)に 示したように, 調查対象粘土の上部と下部で間隙比や含 水比が小さくなっているのは, 堆積環境の違いによる土 性の違いと共に，圧密の進行に密接に関係している。こ

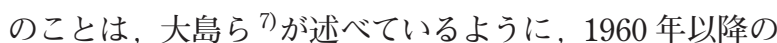
地下水位低下に起因するものと考えられる。つまり，東 大阪粘土の特徵である物理的性質の弓形深度分布は，圧 密履歴とも関連しているといえる。また，定ひずみ速度 圧密試験の過圧密比が段階載荷圧密試験に比べ大きめに 現れるのは，前者が後者に比べて載荷時間が短時間であ ること，および鋭敏粘土のもつ高位な土構造が外力の作 用する速度に対して異なる応答を示すことに関係してい る可能性がある。

Fig. 9 (c) は 2 つの圧密試験方法で求められた圧縮指数 $C_{\mathrm{c}}$ の深度方向の分布である. GL- $12 \mathrm{~m}$ 付近より浅い粘土 と GL- $17 \mathrm{~m}$ 付近より深い粘土では, 両圧密試験方法の $C_{\mathrm{c}}$ がほぼ同じ值を示す。ここでも非海水成粘土の範囲とほ ぼ一致している。逆に，鋭敏比が大きい GL$12 \mathrm{~m} \sim-16 \mathrm{~m}$ 付近の海水成粘土では，定ひず 久速度圧密試験の $C_{\mathrm{c}}$ が段階載荷圧密試験の $C_{\mathrm{c}}$ に比べ数倍大きい. Fig. 10 は, GL-12m

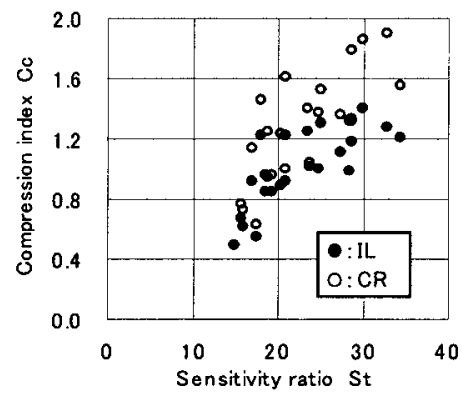

Fig. 10 Sensitivity and compression index.

Fig. 9 Results of consolidation test. 
以深の海水成粘土の鋭敏比 $S_{\mathrm{t}}$ と圧縮指数 $C_{\mathrm{c}}$ の関係であ る。この図でも定ひずみ速度圧密試験の $C_{\mathrm{c}}$ が段階載荷圧 密試験の $C_{\mathrm{c}}$ より大きく現われており，鋭敏比 $S_{\mathrm{t}}$ の増加と ともに $C_{\mathrm{c}}$ も増加する傾向にある。この原因として, 鋭敏 粘土特有の高位な土構造が，ある圧密圧力以上になると 急激に構造破壊を起こすことによるものと考えられる。

\section{$4 \cdot 3$ 圧密試験におけるオーバーシュート現象}

オーバーシュート現象は，ひずみ速度が速くなるほど顕 著になると言わ机てるが，ここではひずみ速度 $0.01 \% /$ $\min$ の定ひずみ圧密試験におけるオーバーシュート現象 について検討する。

Fig. 11 に示すように, オーバーシュート部分から求め た圧密降伏圧力を $p_{1}$ とし, 正規圧密領域の直線部の延長 と $e-\log p$ 曲線との交点の圧密圧力を $p_{2}$ とする。この $p_{1}$ および $p_{2}$ と段階載荷圧密試験の先行圧密荷重 $p_{\mathrm{c}}$ との関係 を Fig. 12 に示す. (a) 図によると, 一部のデータを除い て， $p_{1}$ は $p_{\mathrm{c}}$ より大きく, $p_{\mathrm{c}}<p_{1}<2 p_{\mathrm{c}}$ の範囲である。一方， (b) 困では， $p_{2}$ がほぼ $p_{\mathrm{c}}$ に等しいことがわかる。海水成 粘土のうち過圧密比の大きい試料は $p_{2}=p_{\mathrm{c}}$ 線よりも上に 位置し, 正規圧密に近い試料は $p_{2}=p_{\mathrm{c}}$ 線より下に位置し ており, 圧密応力履歴が関係しているともいえる。

繰り返し荷重下の沖積粘土や大荷重下の洪積粘土に現 れる長期遅れ大沈下は, 間隙比の大きい構造の発達した粘

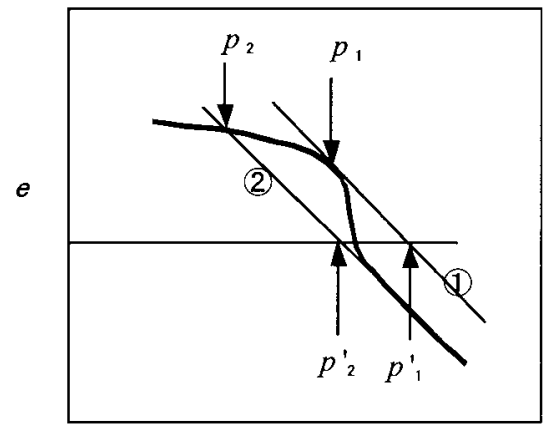

Fig. $11 \quad e-\log p$ curve.
土の構造劣化が原因であり ${ }^{11)}{ }^{12}{ }^{12} \boldsymbol{e}-\log p$ 曲線のオーバー シュート現象として現われ，長期載荷による年代効果に 基づく擬似的な過圧密性とよく似た現象である.6)東大阪 鋭敏粘土で見られる上記のオーバーシュート現象は，海 水成粘土のリーチングにより構造の発達した間隙比の大 きい粘土に，ひずみ速度の大きい定ひずみ圧密試験を実 施した時に生じるものであり, 有効応力状態が圧密降伏 応力を超えた付近から生じる顕著な構造劣化に起因して いると考えられる。

森脇ら ${ }^{11)}$ は, 有明粘土を用いて, オーバーシュートの 表示方法とその意味を追求している. その結果, Fig. 11 に扎いて正規圧密部の直線(2)に平行な直線(1)をオーバー シュート部の $p_{1}$ から引き, 同一の間隙比 $e$ に対する直線 (2) 打よび(1)の圧密圧力を $p_{2}{ }^{\prime}$ 打よび $p_{1}$ 'とすると，圧縮性 から見た鋭敏比 $S_{\mathrm{tc}}=\left(p_{1}{ }^{\prime} / p_{2}{ }^{\prime}\right)$ は，一軸強度から得られ る鋭敏比 $S_{\mathrm{t}}$ とある程度の線形関係が認められることを明 らかにしている。そして有明粘土の堆積過程中に形成さ れた骨格構造の程度を， $S_{\mathrm{tc}}$ によって評価できることを示 している.

ここでは, 森脇らの定義を参考にして, $p_{1}$ と $p_{2}$ の比 $\left(p_{1} / p_{2}\right)$ を求め, 鋭敏比 $S_{\mathrm{t}}$ との関係を Fig. 13 (a) に示す. 森脇らが対象とした粘土は鋭敏比の小さい普通の沖積粘 土であり，今回の鋭敏粘土の骨格構造と同列には考えに くい. そこでFig. 13 (a)に示すように, 粘土中の塩分含 有量 $(\mathrm{Cl}$ 量) により分布範囲を区分すると, $\mathrm{Cl}$ 量別に 鋭敏比 $S_{\mathrm{t}}$ と $\left(p_{1} / p_{2}\right)$ の間に一定の関係がみられる. 粘土 中の $\mathrm{Cl}$ 量は, 堆積環境とその後のリーチングなどの総合 評価であり, これが粘土の構造骨格の程度を決定し, オー バーシュート現象として表現される. $\left(p_{1} / p_{2}\right)$ の代わり に, 段階載荷圧密試験により求められる先行圧密荷重 $p_{\mathrm{c}}$ に対する $p_{1}$ の比 $\left(p_{1} / p_{\mathrm{c}}\right)$ を用いて表すと, Fig. $13(\mathrm{~b})$ とな る.この罒に扎いても $\mathrm{Cl}$ 量および鋭敏比と $\left(p_{1} / p_{\mathrm{c}}\right)$ の関 係が見られる. $\left(p_{1} / p_{2}\right)$ と $\left(p_{1} / p_{\mathrm{c}}\right)$ は, どちらもオーバー シュート部の圧力 $p_{1}$ の程度を表したもので, ここではオー バーシュート比と呼ぶことにする。

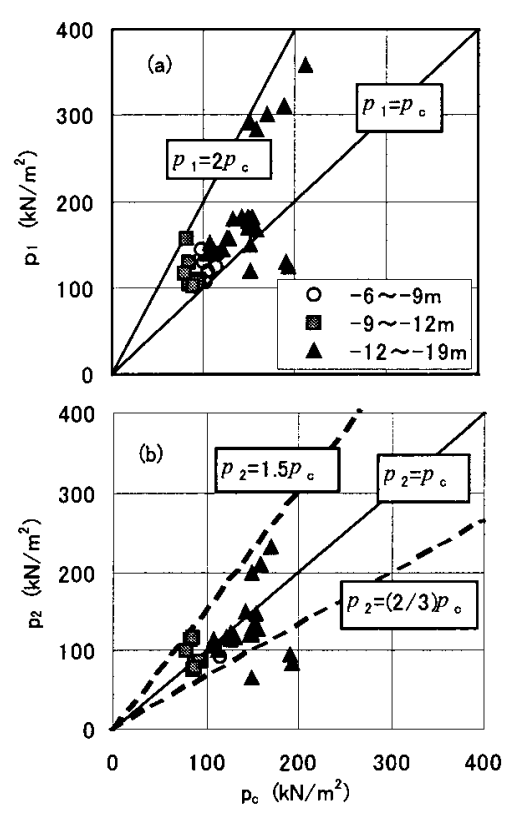

Fig. $12 p_{\mathrm{c}}$ and $p_{1}, p_{2}$.
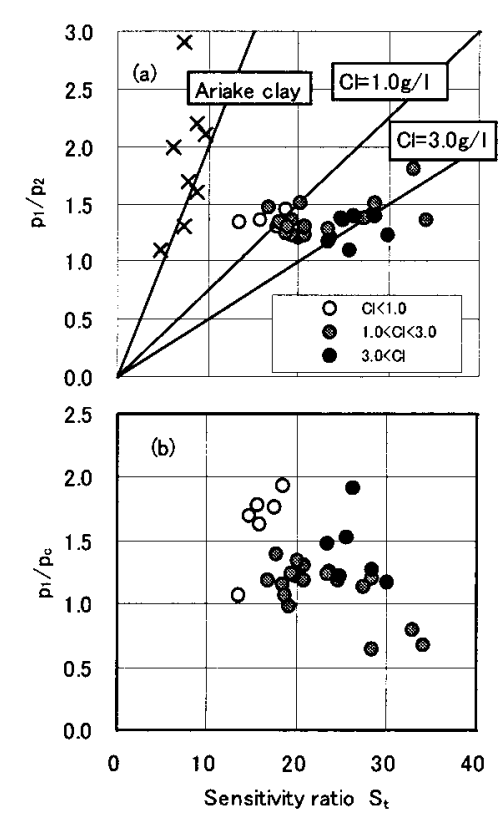

Fig. 13 Overshoot ratio and sensitivity.

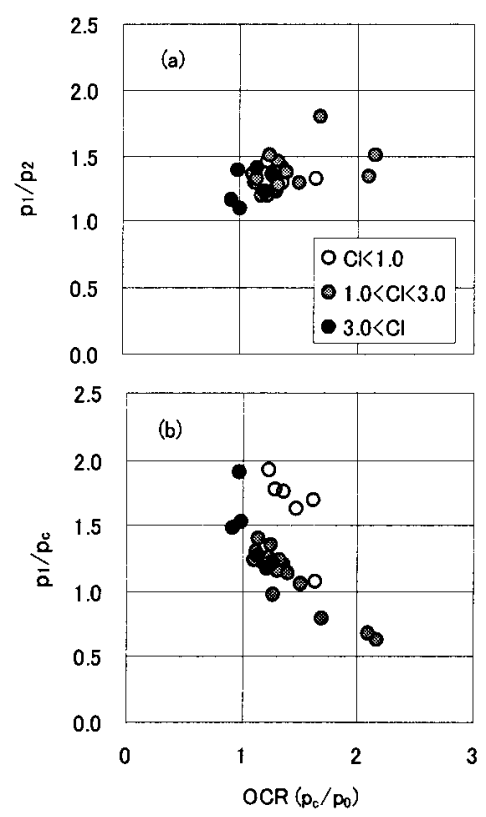

Fig. 14 OCR and overshoot ratio. 
Fig. 14 は, 圧密応力履歴を示す過圧密比 $(\mathrm{OCR}=$ $\left.p_{\mathrm{c}} / p_{0}\right)$ と 2 つオーバーシュート比（ $p_{1} / p_{2}$ あるいは $\left.p_{1} / p_{\mathrm{c}}\right)$ の関係である。(a) 罒では, 過圧密比とオーバー シュート比は関係なく, OCR = 1〜2.5の範囲で，ほぼ一 定のオーバーシュート比である。(b) 図では，オーバー シュート比は OCR と負の相関関係にあるといえる。つま り, 過圧密粘土ではオーバーシュート比は小さく, 逆に, 正規圧密に近い状態ではオーバーシュート比が大きくなる 傾向を示している，さらに，間隙水中の $\mathrm{Cl}$ 量の状態すな わち堆積環境も関係していると考えられる。 また, Fig. 13,14 で見る限り， $\left(p_{1} / p_{\mathrm{c}}\right)$ の方がオーバーシュート現象を 的確に表現しているように見える。ささらにデータを積み重 ねて, オーバーシュート比の意味を追究する必要がある。

$$
5 \text { ま と め }
$$

東大阪の沖積層鋭敏粘土の堆積環境とその後のリーチ ングや圧密過程などを実験的に検討・推察し，その工学 的性質を明らかにした。得られた主な結果は以下のよう である。

(1) 東大阪鋭敏粘土は, 従来から OP-5m -7m（今 回の調査地点では GL-10m 〜 -12m）付近を境として， 上部が非海水成層, 下部が海水成層と区分されており, 今回の調查対象粘土もほぼ同様である。

（2）上部の非海水成層の粒度組成は，その上層（GL$9 \mathrm{~m}$ 以浅) で $P_{2 \mu \mathrm{m}}$ が約 $20 \%$ と一定であり, その下 (GL-9 $-12 \mathrm{~m})$ では下層 (GL-12m 以深) の $P_{2 \mu \mathrm{m}} \fallingdotseq 45 \%$ に向け て漸増している。また, 塩分含有量は上層ほど小さい。 従って, GL-9m 以浅は淡水成, GL-9 -12m は汽水成 と推察できる。

(3) 下部の海水成層は, 粒度特性が一定であり $\left(P_{2 \mu \mathrm{m}} \fallingdotseq\right.$ 45\%), リーチングをかなり受けて鋭敏比が大きい. しか し，その下層ほど塩分含有量と鋭敏比がともに小さく， 下層部は淡水成または汽水成の影響を受けていると考え られる。

（4）その結果, 間隙比, 含水比, コンシステンシー, 塩分含有量などが, GL-12m 付近で膨らんだ弓形の深度 分布を示す.

（5）一軸圧縮強度, 変形係数は直線的に増加する深 度分布であり，粒度組成や塩分含有量で示される堆積環 境にはあまり関係していない.

（6）圧密降伏応力は，含水比などの土性とは逆向きの 弓形深度分布を示し, 粘土層全体が過圧密状態で, とく に非海水成粘土ではその程度が大きい. 1960 年以降の地 下水位低下の痕跡とも考えられる。この結果, 圧縮指数 は, 粘土層中央部の圧縮性が大きい弓形深度分布を呈し, 間隙比, 含水比などの弓形深度分布の原因となっている.

（7）定ひずみ速度圧密試験のオーバーシュート現象 は, 鋭敏粘土の特徵であり, オーバーシュート比 $\left(p_{1} / p_{2}\right.$ あるいは $\left.p_{1} / p_{\mathrm{c}}\right)$ で評価することができる. 今回の調査対 象粘土では, $\left(p_{1} / p_{\mathrm{c}}\right)$ の方がオーバーシュート現象をより 的確に説明できる.オーバーシュート比は, 塩分含有量・ 鋭敏比・過圧密比と一定の関係が得られ，鋭敏粘土の構 造骨格の程度を表現できると考えられるが，なおデータを 積み重ねて追究する必要がある。

\section{参 考 文 献}

1) Kansai Branch of The Japanese Geotechnical Society, Kansai Geotechnical Consultants Association, "Shinpen Osaka Zibanzu”, pp.14-27 (1987) Koronasya.

2) S. Ono, Y. Ando and Y. Yamamoto, "Formation process from old Kawachi bay to lagoon, lake in Higashi-Osaka plain”, The Proceedings of the 34th Japan National Conference on Geotechnical Engineering, JGS, pp.259-260 (1999).

3 ) H. Ohota, T. Hashimoto, Y. Furuta and S. Araki, "Geo physical properties and sedimentary environment of sensitive clay in Higashi-Osaka plain”, The Proceedings of the 34th Japan National Conference on Geotechnical Engineering, JGS, pp.253-254 (1999).

4 ) N. Nakai, T. Konda, S. Ono and S. Nojiri, "The mechanical characteristic of sensitive clay in Higashi-Osaka plain”, The Proceedings of the 34th Japan National Conference on Geotechnical Engineering, JGS, pp.255-256 (1999).

5 ) H. Ito, N. Kitada, M. Mitamura and K. Takemura, "Qualitative complementarity of the borehole database system -The detail examination of geological properties in the Eastern Osaka area using the standard bore hole samples-", The Proceedings of the 41th Japan National Conference on Geotechnical Engineering, JGS, CD-ROM, pp.47-48 (2006).

6 ) T. Fujiwara, Y. Higo, J. Nagaya, A. Oshima, M. Mimura, T. Kodaka, K. Oda and S. Shibuya, "Qualitative complementarity of the borehole database system -The detail examination of geological properties in the Eastern Osaka area using the standard bore hole samples-", The Proceedings of the 41th Japan National Conference on Geotechnical Engineering, JGS, CD-ROM, pp.49-50 (2006).

7 ) A. Oshima, E. Kanya, K. Fumimoto and G. Morioka, "Depth distribution of physical and consolidation properties of Osaka Holocene clay received by dewatering (2nd report)", The Proceedings of the 41th Japan National Conference on Geotechnical Engineering, JGS, CD-ROM, pp.945-946 (2006).

8) JSSMFE, "The foundation and application of chemistry on soil engineering”, The Library for Soil Mechanics and Foundation Engineering No.15, JSSMFE, p.131 (1978).

9 ) N. Miura, T. Akamine and S. Shimoyama, "Study on depositional environment of Ariake clay formation and its sensitivity", Journal of Geotechnical Engineering, JSCE, No.541/ III35, pp.119-131 (1996).

10) Y. Okuda, Y. Nishigaki and D. Tsurumaki, "A Study on the Leaching of Alluvial Clay", The Proceedings of the 15th Japan National Conference on Soil Mechanics and Foundation Engineering, JSSMFE, pp.149-152 (1980).

11) T. Moriwaki and A. Matsui, "Consolidation characteristics of naturally deposited clays and a method for evaluating clay structure", The Proceedings of the 41th Japan National Conference on Geotechnical Engineering, JGS, CD-ROM, pp.219-220 (2006).

12) M. Inagaki, K. Nagao, M. Nakano and T. Noda, "Study on long-term settlement and consolidation characteristics of highly structured clayey soil”, The Proceedings of the 40th Japan National Conference on Geotechnical Engineering, JGS, CD-ROM, pp.1003-1004 (2005). 